\title{
Peningkatan Hasil Belajar Siswa MTs Pada Materi Kesebangunan Dan Kekongruenan Melalui Model Pembelajaran Kooperatif Tipe Jigsaw
}

\author{
Nordina Shaufia', Mayang Gadih Ranti \\ ${ }^{1}$ MTs Modern Puteri Cindai Alus, ${ }^{2}$ STKIP PGRI Banjarmasin \\ *Shaufia.MTsN@gmail.com
}

\begin{abstract}
ABSTRAK
Materi kesebangunan dan kekongruenan merupakan materi bagian dari geometri yang masih sering dianggap sulit bagi siswa. Hal ini terlihat dari rendahnya hasil belajar siswa dan belum tercapainya ketuntasan secara klasikal. Penggunaan alternatif model pembelajaran kooperatif tipe Jigsaw dinilai dapat menjadi alternatif untuk mendorong peningkatan hasil belajar siswa MTs Modern Puteri Cindai Alus karena dapat membuat siswa memiliki rasa tanggung jawab dalam belajar dan mendorong siswa berdiskusi aktif satu sama lain dalam rangka menyelesaikan masalah. Metode Penelitian yang digunakan adalah Penelitian Tindakan Kelas (PTK) yang terdiri atas tahap Perencanaan, Tindakan, Observasi dan Refleksi yang masing-masing dilaksanakan dalam dua siklus, yaitu siklus I dan siklus II. Subjek Penelitian ini adalah 20 orang siswa kelas IX A MTs Modern Puteri Cindai Alus. Teknik pengumpulan Data yang digunakan adalah Tes. Hasil Penelitian menunjukan hasil belajar siswa pada materi kesebangunan dan kekongruenan meningkat dari kategori Cukup ke Baik dan Ketuntasan Secara Klasikal meningkat dari kategori Kurang ke kategori Baik.
\end{abstract}

Kata kunci: Hasil Belajar, Kesebangunan dan Kekongruenan, Model Kooperatif Tipe Jigsaw

\begin{abstract}
Similarity and Congruences is a part of geometry which is considered by students as a difficult Topic. It was detected by a low result study and incompleteness of learning achievement clasiccaly. The using of Learning Copperative Model type Jigsaw is considered as an alternative to improve learning achievement of MTs Modern Puteri Cindai Alus Students because it can make student has a responsibility on their study and make an active discussion in Solving Problem. The research method is Action Research which consists of four steps, Planning, Action, Observation dan Reflection in two cycles. The research subjects are 20 students of Class IX MTs Modern Puteri Cindai Alus. The research results shows that there ia an improving of results study from middle to good category and leaning achivement classicaly improve from less to good category.
\end{abstract}

Kata kunci: Cooperative Model type Jigsaw, Study Resuts, Similarity and Congruences

Received: 2020-07-10

/ Accepted: 2020-09-02

/ Publised: 2020-11-01

\section{Pendahuluan}

Matematika merupakan salah satu mata pelajaran yang diajarkan dari tingkat pendidikan dasar, menengah sampai tingkat pendidikan tinggi. Pada tingkat SMP/Sederajat, tujuan pembelajaran matematika antara lain melatih kemampuan berpikir dan bernalar dalam mengambil kesimpulan, mengembangkan aktivitas kreatif, kemampuan pemecahan masalah dan kemampuan mengkomunikasikan ide-ide atau gagasan. Matematika sekolah berfungsi mengembangkan kemampuan menghitung, mengukur, menurunkan dan menggunakan rumus matematika yang diperlukan dalam kehidupan sehari-hari. Selain itu matematika juga berfungsi mengembangkan kemampuan mengkomunikasikan gagasan dengan bahasa melalui model matematika yang dapat berupa kalimat atau persamaan matematika, diagram, grafik, atau tabel (Rahmah, 2018). 
Matematika sendiri merupakan ilmu yang mendasari ilmu-ilmu yang lain dan berperan penting dalam mengambangkan pola pikir manusia (Mursari, 2019). Matematika yang diajarkan di sekolah mempunyai ciri pada penentuan nalar dan pembentukan sikap siswa yang dimulai dari hal-hal yang konkrit ke hal-hal yang abstrak, dari hal-hal yang mudah ke hal-hal yang sulit dan dari hal-hal yang sederhana ke hal-hal yang kompleks. Matematika memiliki objek yang abstrak dan memiliki pola pikir yang deduktif dan konsisten (Supardi U.S, 2012). Dengan memperhatikan karakteristik matematika di sekolah, maka dapat menjadi acuan dalam menentukan langkah-langkah pembelajaran yang sesuai untuk pembelajaran matematika di sekolah.

Pembelajaran matematika sekolah, khususnya SMP/Sederajat idealnya dimulai dari hal-hal yang bersifat konkrit ke hal-hal yang abstrak. Berdasarkan tahap usia perkembangan menurut Piaget, usia anak kelas IX SMP termasuk dalam tahap operasi formal (12 tahun ke atas). Hasil Penelitian Juwantara (2019) menunjukkan bahwa pada usia 11 sampai 12 tahun ke atas, kemampuan matematika anak semakin kompleks, jika sebelumnya hanya dapat menghitung luas bangun datar, pada fase ini anak sudah bisa menghitung luas, keliling dan volume bangun ruang. Anak-anak sudah mampu memahami hal-hal yang bersifat abstrak.

Kemampuan siswa dalam memahami hal-hal yang bersifat abstrak dalam matematika sangat bergantung pada model atau strategi belajar yang digunakan oleh guru dalam pembelajaran di kelas. Guru harus mampu memilih model atau strategi belajar yang mampu mendorong siswa untuk mendukung ketercapaian kompetensi yang diharapkan, baik dari kompetensi kognitif, afektif, maupun psikomotorik. Hal ini sesuai pula dengan hasil penelitian Juwantara (2019) yang menyimpulkan bahwa model dan metode penanganan yang diberikan guru harus bervariatif sesuai rentang usianya. Penggunaan model dan metode pembelajaran yang tepat dapat mendorong siswa mencapai berbagai kompetensi baik secara kognitif, afektif dan psikomotorik.

Ketercapaian ketiga kemampuan di atas, baik kognitif, afektif dan psikomotorik sama pentingnya. Guru harus mampu merancang pembelajaran yang mendorong tercapainya ketiga kemampuan di atas pada siswa. Dari segi kognitif, dibandingkan mata pelajaran lainnya, pada mata pelajaran lainnya, nilai rata-rata mata pelajaran matematika ataupun ketuntasan klasikal siswa di kelas cenderung lebih rendah. Hal ini disebabkan banyak materi dalam matematika yang bersifat abstrak, misalnya Kesebangunan dan Kekongruenan.

Junaedi (2017) dalam (Sari \& Roesdiana, 2019) menyatakan bahwa geometri merupakan salah satu materi yang sulit dipahami oleh siswa. Wardhani \& Rumiati (2011) dalam (Safrina et al., 2014) menyatakan bahwa berdasarkan hasil studi PISA, hanya $20 \%$ siswa yang dapat menjawab dengan benar salah satu soal pemecahan masalah geometri yang berkaitan dengan konsep keliling persegi, persegi panjang dan jajar genjang. Selain itu, kesulitan belajar geometri juga dialami oleh siswa pada materi kesebangunan dan kekongruenan. Kesulitan siswa dalam kesebangunan dan kekongruenan adalah sulit memahami konsep sisi dan sudut yang bersesuaian, serta membedakan sebangun dan kongruen.

Berdasarkan data hasil belajar siswa kelas IXA MTs Modern Puteri Cindai Alus pada Tahun Pelajaran 2017-2018, pada materi kesebangunan dan kekongruenan diperoleh bahwa dari 20 siswa hanya 7 siswa yang mencapai batas KKM atau hanya 35\% dari jumlah siswa yang mencapai KKM. Rata-rata siswa hanya mendapatkan nilai dibawah 50 dan nilai ini sangat jauh dari batas KKM yang diterapkan disekolah yaitu sebesar 70. Hal ini menyebabkan harus 
dilakukan remedial, namun dari hasil remedial juga tidak memberikan perubahan terhadap hasil belajar siswa. Selain itu minat siswa terhadap pembelajaran matematika khususnya materi kesebangunan dan kekongruenan juga rendah. Hal ini terlihat dari kurang bersemangatnya siswa pada saat mengikuti pelajaran, sehingga terlihat jelas konsentrasi mereka makin lama makin berkurang. Siswa juga masih kurang berinteraksi dikelas, kebanyakan dari mereka masih pasif. Dengan rendahnya minat siswa terhadap pelajaran tersebut berakibat kurangnya daya serap pada materi tersebut ddan akhirnya mengakibatkan hasil belajar menjadi rendah dan tidak mencapai batas KKM yang diterapkan,

Berdasarkan identifikasi masalah di atas, maka terdapat permasalahan yaitu rendahnya hasil belajar siswa kelas IX MTs Modern Putri Cindai Alus pada materi Kesebangunan dan Kekongruenan. Karena jika tidak segera diatasi akan mengakibatkan hasil belajar siswa selalu dibawah batas KKM yang diterapkan disekolah. Oleh karena itu diperlukan model pembelajaran yang dapat menjadi alternatif pembelajaran yang mendorong siswa berpartsipasi aktif dalam pembelajaran dan mampu meningkatkan hasil belajar siswa.

Salah satu model pembelajaran yang dapat menjadi alternatif adalah model pembelajaran kooperatif Tipe Jigsaw. Sanjaya (2010) menyatakan bahwa pembelajaran koperatif tipe iigsaw merupakan model pembelajaran yang dapat meningkatkan keterampilan interpersonal dari setiap anggota kelompoknya. Setiap individu akan saling membantu, mereka akan mempunyai motivasi untuk keberhasilan kelompok, sehingga setiap individu akan memiliki kesempatan yang sama dalam memberikan kontribusi demi keberhasilan kelompoknya. Dalam pembelajaran kooperatif tipe Jigsaw terdapat 3 karakteristik yaitu kelompok kecil, belajar bersama, dan pengalaman belajar. Esensi kooperatif learning adalah tanggung jawab individu sekaligus tanggung jawab kelompok, sehingga dalam diri siswa terbentuk sikap ketergantungan positif yang menjadikan kerja kelompok optimal. Keadaan ini mendukung siswa dalam kelompoknya belajar bekerja sama dan tanggung jawab dengan sungguh-sungguh sampai suksesnya tugas-tugas dalam kelompok. Muslimin (2000) dalam (Abdullah, 2017) menyatakan pembelajaran kooperatif tipe Jigsaw adalah pembelajaran yang lebih menekankan belajar kelompok dengan menggunakan kelompok asal dan kelompok ahli.

Hal ini sesuai pendapat yang dikemukakan oleh Johnson \& Johnson (1991) yang menyatakan bahwa "Pembelajaran Kooperatif tipe Jigsaw ialah kegiatan belajar secara kelompok kecil, siswa belajar dan bekerja sama sampai kepada pengalaman belajar yang maksimal, baik pengalaman individu maupun pengalaman kelompok". Sementara model pembelajaran kooperatif tipe jigsaw sendiri adalah model pembelajaran dengan strategi kelompok belajar yang terdiri dari 4 sampai 6 siswa yang heterogen, baik dari segi kemampuan akademik, jenis kelamin, suku, ras atau sebagainya. Dalam kelompok belajar tersebut terdapat rasa tanggung jawab bersama, ada proses diskusi, saling bertukar pendapat, pembelajaran dengan teman sebaya, kepemimpinan dalam mengatur pembelajaran dikelompoknya sehingga terjalin hubungan yang postifif (Husna \& Hidayati, 2017).

Beberapa penelitian terdahulu juga menunjukkan bahwa model kooperatif tipe Jigsaw dapat meningkatkan hasil belajar matematika siswa. Hasil Penelitian terdahulu dilakukan oleh Rezeki (2009) menunjukkan bahwa pembelajaran kooperatif tipe Jigsaw dapat meningkatkan hasil belajar matematika siswa kelas VIII G SMPN 2 Toroh Grobogan. Model Penelitian Kooperatif tipe JIGSAW juga dapat meningkatkan hasil belajar matematika siswa kelas VIII-3 SMP Negeri 30 Pekanbaru Tahun pelajaran 2013/2014. (Yusra, 2015). 
Berdasarkan penelitian-penelitian terdahulu, penggunaan model kooperatif tipe Jigsaw telah mampu meningkatkan hasil belajar matematika siswa SMP. Penggunaan model kooperatif tipe Jigsaw dapat dijadikan alternatif pada pembelajaran materi geometri khususnya kesebangunan dan kekongruenan. Sesuai dengan hasil penelitian Islami et al. (2019) diperoleh bahwa kesulitan siswa kelas IX dalam menyelesaikan soal-soal kesebangunan dan kekongruenan terbesar pada menerapkan konsep dan berhitung. Model kooperatif tipe jigsaw dapat memaksimalkan keaktifan siswa dalam mengumpulkan informasi, berdiskusi dan saling membantu dalam belajar konsep-konsep matematika sehingga mampu meningkatkan pemahaman konsep (Istihapsari, 2017).

Berdasarkan uraian di atas, adanya kesesuaian antara model pembelajaran koperatif tipe jigsaw dengan upaya peningkatkan keaktifkan yang berakibat pada peningkatan pemahaman konsep siswa, maka akan dilakukan penelitian dengan menggunakan model pembelajaran koopeatif tipe jigsaw dalam rangka meningkatkan hasil belajar siswa kelas IX MTs Modern Puteri Cindai Alus. Tujuan Penelitian ini adalah untuk mengetahui peningkatan hasil belajar siswa kelas IX MTs Modern Puteri Cindai Alus pada materi kesebangunan dan kekongruenan.

\section{Metode Penelitian}

Metode Penelitian yang digunakan adalah Penelitian Tindakan Kelas (PTK). Menurut Arikunto (2006) dalam (Mulia \& Suwarno, 2016) Penelitian Tindakan Kelas terdiri dari Penelitian, Tindakan dan Kelas. PTK adalah Kegiatan mencermati suatu objek untuk memperoleh data yang bermanfaat dalam meningkatkan mutu suatu hal, dengan suatu tindakan pada sekelompok siswa yang dalam waktu yang sama menerima pelajaran yang sama dari seorang guru. Dalam Penelitian ini, PTK dilaksanakan dalam empat tahap yaitu Perencanaan, Pelaksanaan Tindakan, Observasi dan Refleksi. Penelitian Tindakan Kelas (PTK) ini dilaksanakan sebanyak 2 siklus, yaitu siklus I dan siklus II. Setiap siklus dilaksanakan 2 kali pertemuan. Desain penelitian dapat dilihat pada gambar 1 berikut:

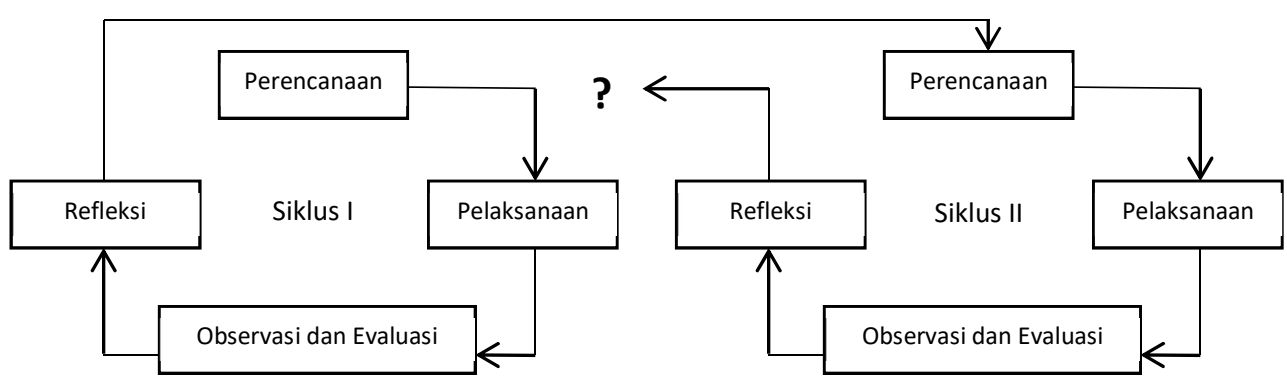

Gambar 1. Desain Penelitian

Prosedur PTK untuk memperoleh data tentang proses dan hasil yang akan dicapai pada penelitian ini dilakukan pada beberapa proses dan tahapan yaitu sebagai berikut :

1. Perencanaan tindakan (Planning)

Kegiatan dalam perencanaan yaitu meliputi langkah-langkah tindakan yang lebih rinci. Pada tahap perencanaan, beberapa hal yang dipersiapkan oleh guru sebagai peneliti, yaitu sebagai berikut: 
a. Menyusun RPP Matematika Kelas IX Kurikulum KTSP pada materi kesebangunan

b. Menyiapkan media belajar dan sumber belajar yang akan digunakan dalam pembelajaran matematika pada materi kesebangunan dengan menggunakan model pembelajaran kooperatif tife jigsaw

c. Menyiapkan LKS yang nantinya akan digunakan dalam kegiatan diskusi kelompok

d. Menyiapkan instrumen penelitian berupa soal-soal tes, lembar aktivitas guru dan siswa

e. Melakukan koordinasi dengan observer mengenai pelaksanaan tindakan di dalam kelas.

2. Melaksanakan tindakan (Action)

Pelaksanaan tindakan didalam penelitian ini yaitu menggunakan model pembelajaran kooperatif tife jigsaw. Dalam pelaksanaannya guru berusaha untuk mengaplikasikan perencanaan yang telah disusun secara matang, namun demikian tindakan yang dilakukan harus bersifat dinamis dan fleksibel yang disesuaikan dengan situasi dan kondisi di dalam kelas.

3. Pengamatan (observing)

Observasi dalam penelitian ini dilakukan dengan cara memberikan penilaian secara langsung pada lembar observasi yang telah disusun sesuai komponen yang diharapkan. Pada tahapan ini dilakukan proses pengamatan sebagai upaya merekam segala peristiwa dan kegiatan yang terjadi selama pelaksanaan tindakan berlangsung. Observer mengamati pelaksanaan model pembelajaraan kooperatif tife jigsaw.

4. Refleksi (Reflection)

Kegiatan refleksi ini dilakukan setelah berlangsungnya tindakan. Beberapa kegiatan yang dilakuka pada tahap refleksi adalah berupa analisis, sintesis, penafsiran, menjelaskan dan menyimpulkan hasil-hasil yang diperoleh selama dilaksanakannya tindakan. Hasil refleksi ini digunakan untuk menentapkan langkah lebih lanjut dalam upaya mencapai hasil lebih optimal disiklus selanjutnya.

Penelitian ini dilaksanakan selama 6 bulan yaitu dari bulan Mei - Oktober 2018. Penelitian dilaksanakan di MTs. Modern Puteri Cindai Alus yang beralamat di jalan Cindai Alus No. 14 RT.07 RW.03 Kecamatan Martapura 70612. Subjek dalam penelitian ini adalah seluruh peserta didik kelas IX A MTs. Modern Puteri Cindai Alus Semester Ganjil Tahun Pelajaran 2018/2019 yang berjumlah 20 0rang, sedangkan objek penelitiannya yaitu hasil belajar siswa pada materi kesebangunan dan kekongruenan.

Teknik yang digunakan untuk pengumpulan data dalam penelitian ini adalah Tes, yaitu Tes Tertulis. Tes tertulis dilakukan pada setiap akhir siklus yang tujuannya mengetahui peningkatan hasil belajar siswa pada materi kesebangunan dan kekongruenan melalui model pembelajaran kooperatif tipe Jigsaw.

Untuk menganalisis data hasil belajar siswa digunakan langkah-langkah sebagai berikut:

a. Menentukan hasil belajar siswa secara individual menggunakan rumus :

$$
N=\frac{\text { Skor perolehan }}{\text { Skor maksimal }} \times 100 \quad \mathrm{~N}=\text { Nilai Akhir }
$$

Berdasarkan nilai yang diperoleh kemudian ditentukan nilai rata-rata kelas yang diklasisikasikan sesuai tabel 1 yang diadaptasi dari (Arikunto, 2013) sebagai berikut. 
Tabel 1. Klasifikasi Hasil Belajar Siswa

\begin{tabular}{|c|c|}
\hline Interval Nilai & Klasifikasi \\
\hline $80<x \leq 100$ & Sangat Baik \\
\hline $65<x \leq 80$ & Baik \\
\hline $55<x \leq 65$ & Cukup \\
\hline $40<x \leq 55$ & Kurang \\
\hline $0<x \leq 40$ & Sangat Kurang \\
\hline
\end{tabular}

b. Menentukan ketuntasan siswa secara klasikal menggunakan rumus :

Persentase $=\frac{\text { Jumla Siswa Yang Tuntas }}{\text { Jumla Total Siswa }} \times 100 \%$

Secara klasikal ketuntasan hasil belajar suatu kelas dicapai apabila paling sedikit 70\% siswa dikelas tersebut tuntas belajar secara individu. Rata-rata nilai hasil belajar siswa diklasifikasikan sesuai tabel 2 berikut:

Tabel 2. Klasifikasi Ketuntasan Klasikal Siswa

\begin{tabular}{|c|c|}
\hline Presentase & Klasifikasi \\
\hline $91-100 \%$ & Amat Baik \\
\hline $76-90 \%$ & Baik \\
\hline $61-75 \%$ & Cukup \\
\hline $51-60 \%$ & Kurang \\
\hline$\leq 50 \%$ & Sangat Kurang \\
\hline
\end{tabular}

Indikator keberhasilan yang ditetapkan peneliti pada PTK ini yaitu hasil belajar siswa berada pada kategori baik dan sebanyak $70 \%$ dari jumlah siswa kelas IX A MTs. Modern Puteri Cindai Alus yang hasil belajarnya pada materi kesebangunan dan kekongruenan mencapai KKM yaitu 70,00 .

\section{Hasil dan Pembahasan}

Pembelajaran dengan menggunakan model kooperatif tipe Jigsaw telah efektif dalam meningkatkan hasil belajar siswa kelas IX A MTs Modern Putri Cindai Alus pada materi kekongruenan dan kesebangunan. Hal ini terlihat dari adanya peningkatan hasil belajar dari siklus I ke siklus II dari kategori kurang ke kategori baik. Hal ini disebabkan adanya peningkatan aktivitas belajar yang dilakukan oleh siswa melalui pembelajaran kooperatif tipe Jigsaw, yaitu melalui kegiatan diskusi kelompok, tanya jawab dan adanya rasa tanggung jawab dari masing-masing anggota Tim Ahli untuk dapat menjelaskan materi ke anggota Tim Asal yang mendorong masing-masing siswa untuk berusaha semaksimal mungkin memahami materi yang diberikan.

Pelaksanaan penelitian ini dilakukan dalam 2 siklus yaitu siklus I dan siklus II. Masing-masing siklus terdiri atas 4 kali pertemuan dengan alokasi waktu $2 \times 40$ menit setiap pertemuan yang terdiri atas 3 kali pertemuan pemberian materi dan 1 kali pertemuan evaluasi hasil pembelajaran. Pertemuan pertama dilakukan pada hari Rabu, tanggal 1 Agustus 2018 jam pelajaran ke 2-3 dengan materi tentang konsep dan sifat-sifat kesebangunan bangun datar. Pertemuan kedua pada hari Sabtu, tanggal 4 Agustus 2018 jam pelajaran ke 4-5 dengan materi tentang sifat dua segitiga yang sebangun. Pertemuan ketiga pada hari Rabu, tanggal 8 Agustus 2018 jam pelajaran ke 2-3 dengan materi tentang perbandingan keebangunan dalam segitiga. Pertemuan keempat pada hari Sabtu, tanggal 11 Agustus 2018 jam pelajaran ke 4-5. Pada 
pertemuan keempat ini dilaksanakan evaluasi pembelajaran pada siklus I. Pada evaluasi ini siswa diberikan 5 soal yang berisikan materi tentang mengidentifikasi bangun-bangun datar yang sebangun dan kongruen serta mengidentifikasi sifat-sifat dua segitiga sebangun dan kongruen.

Adapun hasil Belajar siswa pada materi kesebangunan dan kekongruenan pada siklus I pada siklus I dapat dilihat pada tabel 3 di bawah ini :

Tabel 3. Hasil Evaluasi Siswa Pada Siklus I

\begin{tabular}{|c|c|c|c|}
\hline $\begin{array}{c}\text { Interval } \\
\text { Nilai }\end{array}$ & Frekuensi & Presentase (\%) & Keterangan \\
\hline $90-100$ & 0 & 0 & Amat Baik \\
\hline $80-89$ & 5 & 25 & Baik \\
\hline $70-79$ & 5 & 25 & Cukup \\
\hline $50-69$ & 8 & 40 & Kurang \\
\hline$\leq 50$ & 2 & 10 & Sangat Kurang \\
\hline
\end{tabular}

Secara individual, mayoritas siswa berada pada kualifikasi kurang yaitu sebesar $40 \%$, Secara keseluruhan rata-rata hasil belajar siswa pada siklus I adalah 65. Nilai ini termasuk kategori cukup. Secara klasikal terdapat 10 dari 20 siswa yang nilainya mencapai KKM atau ketuntasan klasikalnya hanya sebesar $50 \%$ dan berada pada kategori kurang

Berdasarkan hasil yang diperoleh, dilakukan refleksi berupa analisis dan penafsiran untuk menjelaskan dan menyimpulkan hasil-hasil yang diperoleh selama dilakukannya tindakan. Hasil refleksi ini digunakan untuk menetapkan langkah lebih lanjut dalam upaya mencapai hasil lebih optimal di siklus selanjutnya. Refleksi utamanya dilakukan pada pengoptimalan kegiatan diskusi siswa pada kegiatan pembelajaran di siklus II.

Pelaksanaan siklus II pertemuan pertama dilakukan pada hari Rabu, tanggal 15 Agustus 2018 jam pelajaran ke 2-3 dengan materi tentang Perbandingan panjang sisi dua segitiga yang sebangun. Pertemuan kedua pada hari Sabtu, tanggal 18 Agustus 2018 jam pelajaran ke 4-5 dengan materi tentang konsep dan sifat kekongruenan bangun datar. Pertemuan ketiga pada hari Rabu, tanggal 22 Agustus 2018 jam pelajaran ke 2-3 dengan materi tentang penerapan konsep kesebangunan dan kekongruenan dalam kehidupan. Pertemuan keempat pada hari Sabtu, tanggal 25 Agustus 2018 jam pelajaran ke 4-5. Pada pertemuan keempat ini dilaksanakan evaluasi pembelajaran pada siklus II. Pada evaluasi ini siswa diberikan 5 soal yang berisikan materi tentang sifat-sifat dua segitiga sebangun dan kongruen serta penggunaan konsep kesebangunan segitiga dalam pemecahan masalah. Pada siklus II, diperoleh hasil belajar yang lebih baik dari siklus I. Kualifikasi hasil siswa pada siklus II dapat dilihat pada tabel 4 di bawah ini :

Tabel 4 Hasil Evaluasi Siswa Pada Siklus II

\begin{tabular}{|c|c|c|c|}
\hline $\begin{array}{c}\text { Interval } \\
\text { Nilai }\end{array}$ & Frekuensi & Presentase (\%) & Keterangan \\
\hline $90-100$ & 2 & 10 & Amat Baik \\
\hline $80-89$ & 10 & 50 & Baik \\
\hline $70-79$ & 5 & 25 & Cukup \\
\hline $50-69$ & 3 & 15 & Kurang \\
\hline$\leq 50$ & 0 & 0 & Sangat Kurang \\
\hline
\end{tabular}

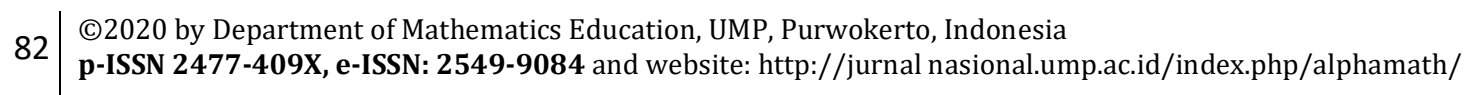


Berdasarkan hasil evaluasi diakhir siklus II, diperoleh rata-rata nilai hasil evaluasi belajar meningkat menjadi 77,5 dan ketuntasan klasikal juga meningkat menjadi sebesar $85 \%$, dimana 17 dari 20 siswa mencapai KKM. Rata-rata hasil belajar dan ketuntasan secara klasikal keduanya termasuk kategori Baik. Terdapat 2 siswa yang berada pada katagori amat baik atau sekitar 10\%, 10 siswa yang berada pada katagori baik atau sekitar 50\%, 5 siswa yang berada pada katagori cukup atau sekitar 25\%, dan 3 siswa yang berada pada katagori kurang atau 15\%. Adapun untuk melihat peningkatan hasil belajar siswa dari siklus I dan II dapat dilihat dari gambar 2 berikut:

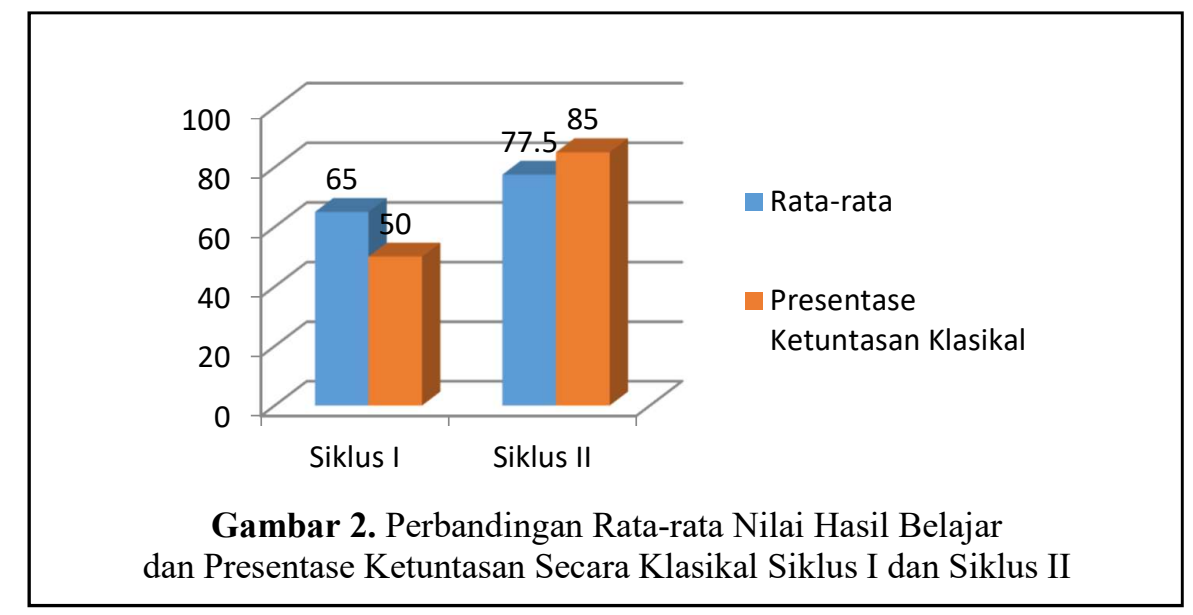

Berdasarkan gambar di atas, diperoleh terjadi peningkatan hasil belajar baik dari segi rata-rata nilai ataupun ketuntasan secara klasikal. Hal ini dikarenakan siswa sudah mulai terbiasa dengan model kooperatif tipe Jigsaw ini, siswa sudah berani berdiskusi didalam kelompoknya sehingga waktu pembelajaran yang tersedia bisa berjalan dengan maksimal. Dengan aktifnya siswa didalam pembelajaran ini menyebabkan daya serap hasil belajar siswa pada materi kesebangunan dan kekongruenan bisa meningkat dan sudah memenuhi KKM. Hasil belajar siswa secara secara individu maupun klasikal sudah memenuhi KKM, sehingga hipotesis tindakan dapat diterima yaitu melalui model Pembelajaran Kooperatif Tipe Jigsaw dalam pembelajaran matematika kelas IX A di MTs Modern Puteri Cindai Alus dapat meningkatkan hasil belajar siswa pada materi kesebangunan dan kekongruenan.

Peningkatan hasil belajar yang diperoleh disebabkan oleh adanya pembaruan terhadap model belajar yang digunakan. Dalam hal ini penggunaan model kooperatif tipe JIGSAW telah mampu mendorong siswa terlibat aktif dalam pembelajaran, sehingga siswa pada akhirnya dapat memahami materi dengan lebih baik. Seperti yang disampaikan Lie (2004) dalam (Lubis \& Harahap, 2016) bahwa Model Kooperatif tipe Jigsaw didesain untuk meningkatkan rasa tanggung jawab siswa terhadap pembelajarannya sendiri dan pembelajaran orang lain. Pada model pembelajaran tipe Jigsaw adanya kelompok asal dan kelompok ahli membuat siswa untuk lebih termotivasi dalam memahami materi, karena nantinya harus menjelaskan kepada teman-temannya di kelompok asal. Sesuai dengan yang disampaikan Sudarajat (2008) dalam (Suprihatin, 2017) bahwa tipe pembelajaran kooperatif Jigsaw adalah pembelajaran yang dilakukan dengan berkelompok dan mampu mengajarkan materi tersebut ke kelompok lainnya.

Pembelajaran menggunakan Model Kooperatif tipe Jigsaw dalam pembelajaran dapat memunculkan lebih banyak kegiatan bagi siswa. Proses Pembelajaran matematika yang berlangsung di sekolah saat ini masih banyak yang didominasi guru, dimana guru sebagai 
sumber utama pengetahuan sehingga guru memegang peranan penting dalam pelaksanaan pembelajaran (Septiani, 2018). Dengan model kooperatif tipe Jigsaw guru hanya lebih berperan sebagai fasilitator dalam pembelajaran yaitu membimbing siswa bekerja dalam kelompok dan siswa menjadi pusat pembelajaran yang terlibat aktif dalam penemuan atau pemahaman konsep materi yang diajarkan.

\section{Simpulan}

Berdasarkan hasil dan pembahasan, diperoleh kesimpulan bahwa terdapat peningkatan hasil belajar siswa kelas XI MTs Modern Puteri Cindai Alus pada materi Kesebangunan dan Kekongruenan yaitu meningkat dari siklus I ke Siklus II yaitu dari kateogori cukup ke baik. Selain itu, dilihat dari ketuntasan secara klasikal juga mengalami peningkatan dari kategori kurang ke kategori baik.

Bagi peneliti selanjutnya, dapat menggunakan alternatif model kooperatif tipe lainnya dalam rangka meningkatkan hasil belajar siswa, khususnya pada materi kesebangunan dan kekongruenan. Bagi guru dan siswa, penelitian ini juga dapat menjadi suatu alternatif pilihan dalam pembelajaran matematika

\section{Daftar Pustaka}

Abdullah, R. (2017). Pengaruh Penerapan Model Pembelajaran Kooperatif Tipe Jigsaw Pada Mata Pelajaran Kimia Di Madrasah Aliyah. Lantanida Journal, 5(1), 13. https://doi.org/10.22373/lj.v5i1.2056

Arikunto, S. (2013). Dasar-dasar Evaluasi Pendidikan. PT Bumi Aksara.

Husna, A., \& Hidayati, L. (2017). Penerapan Model Pembelajaran Kooperatif Tipe Jigsaw Pada Kompetensi Dasar Membuat Pola Lengan Secara Konstruksi Siswa Kelas X Tata Busana 4 Smk Negeri 6 Surabaya Tahun Pelajaran 2016 / 2017 Asma' ul Husna Lutfiyah Hidayati Abstrak. E-Journal, 06(3), 24-31.

Islami, A. N., Rahmawati, N. K., \& Kusuma, A. P. (2019). Analisis Kesulitan Siswa Dalam Menyelesaikan Soal Matematika Pada Materi Kekongruenan dan Kesebangunan. Simposium Nasional Ilmiah Dengan Tema Peningkatan Kualitas Publikasi Ilmiah Melalui Hasil Riset Dan Pengabdian Kepada Masyarakat, 158-170. https://doi.org/10.30998/simponi.v0i0.444.

Istihapsari, V. (2017). Meningkatkan Pemahaman Konsep Materi Matematika Smp Menggunakan Model Pembelajaran Kooperatif Tipe Jigsaw Pada Mahasiswa Prodi Pendidikan Matematika Uad. AdMathEdu: Jurnal Ilmiah Pendidikan Matematika, Ilmu $\begin{array}{lllll}\text { Matematika Dan } & \text { Matematika }\end{array}$ https://doi.org/10.12928/admathedu.v7i1.7404.

Johnson, D. W., \& Johnson, R. T. (1991). Learning Together and Alone, Cooperative, Competitive and Individualistic Learning. Allyn and Bacon.

Juwantara, R. A. (2019). Analisis Teori Perkembangan Kognitif Piaget pada Tahap Anak Usia Operasional Konkret 7-12 Tahun dalam Pembelajaran Matematika. Al-Adzka: Jurnal Ilmiah Pendidikan Guru Madrasah Ibtidaiyah, 9(1), 27. https://doi.org/10.18592/aladzkapgmi.v9i1.3011.

Lubis, N. A., \& Harahap, H. (2016). Pembelajaran Kooperatif Tipe Jigsaw. Jurnal As-Salam, 1(1), 96-102. http://jurnal-assalam.org/index.php/JAS/article/view/48.

Mulia, D. S., \& Suwarno. (2016). PTK (Penelitian Tindakan Kelas) Dengan Pembelajaran Berbasis Kearifan Lokal Dan Penulisan Artikel Ilmiah Di SD Negeri Kalisube, Banyumas. Khazanah Pendidikan Jurnal Ilmiah Kependidikan, Vol. IX, No. 2 (Maret 2016) PTK, 
$I X(2), 11$. http://jurnalnasional.ump.ac.id/index.php/khazanah/article/view/1062/983.

Mursari, C. (2019). Deskripsi Kemampuan Berikir Kritis Matematis dan Kemandirian Belajar Siswa Ditinjau dari Gaya Belajar. Journal of Mathematics Education Alphamath, 5(2), 40-48. https://doi.org/http://dx.doi.org/10.30595/alphamath.v5i2.7345.

Rahmah, N. (2018). Hakikat Pendidikan Matematika. Al-Khwarizmi: Jurnal Pendidikan Matematika Dan Ilmu Pengetahuan Alam, 1(2), 1-10. https://doi.org/10.24256/jpmipa.v1i2.88.

Rezeki, N. E. S. (2009). Meningkatkan Hasil Belajar. Jurnal LEMLIT, 3(2), 61-73.

Safrina, K., Ikhsan, M., \& Ahmad, A. (2014). Peningkatan Kemampuan Pemecahan Masalah Geometri melalui Pembelajaran Kooperatif Berbasis Teori Van Hiele. 1(1), 9-20. https://doi.org/10.24815/jdm.v1i1.1238.

Sanjaya, W. (2010). Strategi Pembelajaran Berorientasi Standar Proses. Prenada Media Grup. Sari, M. M., \& Roesdiana, L. (2019). Analisis Kesulitan Belajar Siswa SMA pada Pembelajaran Geometri 1. 10(2), 209-214.

Septiani, T. (2018). Upaya Meningkatan Kemampuan Berpikir Kritis Siswa. Alphamath: Journal of Mathematics Education, 4(1), 33-45.

Supardi U.S. (2012). Peran Berpikir Kreatif Dalam Proses. Jurnal Formatif, 2(3), 248-262.

Suprihatin, S. (2017). -Issn 2337-4721. Pengaruh Model Pembelajaran JIGSAW Terhadap Hasil Belajar Studi Masyarakat Indonesia Mahasiswa, 5(1), 39.

Yusra. (2015). Yusra - Penerapan Model Pembelejaran Kooperatif Jigsaw Untuk Meningkatkan Hasil Belajar Matematika Pada Siswa Kelas VIII-3 SMP Negeri 30 Pekanbaru Tahun Pelajaran 2013/2014. Suara Guru: Jurnal Ilmu Pendidikan Sosial, Sains Dan Humaniora, 1(1), 55-68. 